\title{
VISIBILITY ANALYSIS OF FIRE LOOKOUT TOWERS PROTECTING THE MEDITERRANEAN FOREST ECOSYSTEMS IN TURKEY
}

\author{
ANALIZA VIDLJIVOSTI VATROGASNIH TORNJEVA \\ NAMIJENJENIH ZAŠTITI MEDITERANSKIH ŠUMSKIH \\ EKOSUSTAVA OD POŽARA U TURSKOJ
}

\author{
Hüseyin Oǧuz ÇOBAN $1{ }^{1,}$, Halis BEREKET ${ }^{2}$
}

\begin{abstract}
SUMIMARY
Urgent detection of fire and precise identification of its location are of critical importance for success of first response to fight forest fire. Forest fire lookout towers are main observation system and used in a sophisticated way to detect forest fires in Turkey. The objective of this study was to conduct visibility analysis of fire lookout towers deployed in mountainous Mediterranean forest region of Turkey, thereby assess their effectiveness. It is necessary to determine functionality and capacity of these towers to protect forest environment. Visible and invisible areas from towers were identified by using Geographic Information System and high resolution digital elevation data. In visibility analysis, scanning was performed with a rotation of 360 degrees at the 18 kilometres radius from the point where a lookout tower was located. Roads in this region are one of the elements that can be used in fire observation. People traveling on these roads may report forest fires by using cell phones. In this sense, the efficiency/effectiveness of the towers have been associated with forest road traffic. Therefore, visibility analysis of roads was also performed to check the observation capabilities from roads. Although there are 37 fire lookout towers in this area, where coniferous tree species such as brutian pine and black pine that are highly vulnerable to fire are dominantly distributed, $40 \%$ of forests are in parts that are not visible and 15\% of them are at high risk of fire. More than 100 thousand hectares of firesensitive forest area in this region could not be controlled by the towers. The network of towers could view $56 \%$ of the overall area and $59 \%$ of the forest areas. People using the roads contributed to the lookout system by $11 \%$ and ensured that $70 \%$ of the forest area in this region was visible when combined with the towers. On the other hand, $59 \%$ of 523 thousand hectares of forest land that were not visible from the roads were visible from the towers. It was emphasized that the participatory behavior of people who lived in forests and used inner forest roads were an important part of the fire observation system. We recommend that the GIS-based methodologies including digital camera systems and remote sensing technologies in addition to the conventional lookout towers with a view to planning the economically, technically and operationally optimal fire lookout system.
\end{abstract}

KEY WORDS: viewshed analysis, fire risk, fire sensitivity, forest fire, forest road, Isparta

\section{INTRODUCTION}

\section{UVOD}

As a natural phenomenon of Mediterranean forest ecosystem (Pausas and Vallejo, 1999; Keeley et al., 2012), forest fires can help their regeneration (Wuertner, 2006; Neyişçi, 2009). The survival of those ecosystems depends on their resilience and adaptability (Daniau et al., 2010; Keeley, 2012; San-Miguel-Ayanz et al., 2013). Moreover, economic and

\footnotetext{
${ }^{1}$ Assoc. Prof. Dr. for Hüseyin Oǧuz Çoban, Isparta University of Applied Sciences, Faculty of Forestry, 32260, Isparta, Turkey

${ }^{2}$ M.Sc. for Halis Bereket, Süleyman Demirel University, Graduate School of Natural and Applied Sciences, 32260, Isparta, Turkey, e-mail: mail@halisbereket.com

*Correspondence: oguzcoban@isparta.edu.tr
} 
social negative impacts of forest fires (Küçükosmanoğlu, 1986; Garbolino et al., 2017) cannot be ignored. It is life threatening for people if forest fire goes beyond the scale that can be controlled and turns into a gigantic fire (MolinaTerre' $\mathrm{N}$ et al., 2019). Restoration and rehabilitation of areas destroyed due to forest fire require high cost, long time and a big labour force (Eker and Çoban, 2009; Naama et al., 2019). Therefore, forest fires should be detected and extinguished in the shortest time possible (Cao et al., 2019). Along the south and west coast of Turkey, forests that are distributed in areas adjacent to the Mediterranean and Aegean Sea and under the influence of Mediterranean climate are first-degree fire-sensitive areas (Bilgili et al., 2001; Bilici et al., 2017; Çoban and Erdin, 2020). This region also contains special conservation areas such as national parks, wildlife promotion areas and archaeological conservation sites. Uninterrupted lookout throughout the fire season is extremely important for these high fire-risk areas.

The statistics of the European Union show that 63724 forest fires that broke out in Turkey from 1988 to 2017, 319 848 hectares burned down (JRC, 2018). More than $90 \%$ of those forest fires are man-made (Avci et al., 2009; JRC, 2018). Every year more than 10 thousand hectares of forest area is burnt in Turkey (GDF, 2019). These figures indicate that Turkey faces a serious threat of forest fire.

When fire prevention fails, firefighting process starts (Çanakçıoglu, 1993). The first step of this process is to immediately identify the origin of the fire. It depends on noticing fire in the short time possible to extinguish it before it grows further. Delayed action of identifying the fire ignition location also delays response by the first teams and that may allow the fire to grow bigger and burn large areas (Rodrigues et al., 2019).

In Turkey, the primary method used for early detection of forest fire is the network of fire lookout towers installed on 774 lookout points (GDF, 2019). Being installed for an effective fire detection system and playing an important role for the success of first response to fire, this lookout system reduces the fire extinguishing costs substantially (Rego and Catry, 2006; Catry et al., 2007; Pompa-Garcia et al., 2010). Two people assigned at towers lookout for possible fires with binoculars uninterruptedly 24 hours a day for almost 4 months. When fire is detected from the tower, the coordinates of the fire point are determined and emergency response teams are alerted. Tower officers monitor the status of the fire on one hand while on the other hand they navigate the teams in the field. Moreover, in fire-sensitive Mediterranean and Aegean regions, there are only a few fire lookout towers that are endowed with smoke detection sensors and thermal camera systems (Kolaric et al., 2008; Wooster et al., 2013). These sensors are reported to have a very high rate of sensing fire as long as they are not influ- enced by mist and fog (Küçük et al., 2017). In case of a meteorological alert, mobile first response teams and air surveillance (helicopters/planes) can be mobilized in the forest areas that are very sensitive to fire.

Fire lookout towers in Turkey are reported to have been built in 1946 (Çanakçıŏlu, 1993). Visibility analyses, that was once made on printed maps, can now be performed more quickly, precisely and with multiple dimensions in digital settings. Geographical Information System (GIS) is an effective tool to process digital surface data (Çoban and Eker, 2010; Yener, 2013) and to assess the locations of fire lookout towers on digital maps according to the designated criteria (Așkın, 2004). In addition to the positioning of visible and invisible areas from the towers, GIS-based multidimensional assessment can be made through viewing the fire-sensitive areas from minimum two towers, processing and inquiring dangerous areas, picnic sites, energy transmission lines agricultural fields and settlement areas on different geographical layers. There are relatively few studies about the viewshed analyses at forest fire lookout towers in Turkey. In a study conducted in Boyabat in the West Black Sea Region, $73 \%$ of the forest area was reported to be visible from 6 fire lookout towers (Küçük et al., 2017). Another study was conducted in Ilgaz which was located in the same region (Kudu and Buğday, 2019). In a study conducted in Gallipoli Peninsula, 73\% of the forest area was reported to be visible from 14 towers (Akbulak and Özdemir, 2008). Aşkın (2004) conducted a study in İzmir in the west, Akay et al. (2011) performed a study in Andırın in Kahramanmaraş region and Akay and Erdoğan (2017) conducted a study in Dursunbey-Balıkesir.

Fire lookout towers are an indispensable communication system despite the technological developments regarding the sensation of fire and notification of response teams about the fire including its location. The main function of these towers is the scanning of an area by a watchman on a regular basis at certain intervals. Therefore, these towers should be positioned in locations where a wide physical space can be visible and that have a wide field of view. There is a need to determine and assess the viewshed capacity of these towers that were positioned mainly on the basis of two dimensional map cross-section in the past. Several destructive fires break out in the Mediterranean forest ecosystems where first-degree fire-sensitive brutian pine and black pine species are widely distributed (GDF, 2019). Today, the effectiveness of the existing towers can be determined through analysis and assessment processes based on GIS that is capable of processing fine data such as digital maps and satellite data.

The objective of this study was to conduct visibility analysis of fire lookout towers by using GIS techniques, determine the visible and invisible areas and analyse the fire risk of fo- 
rest areas that are invisible or outside detection range. The roads were considered to be part of the fire observation system with many observation points on them. People using roads passing through forests was reporting fires to the authorized officers, immediately. Therefore, visibility analysis of roads was also performed to check their observation potential in this region.

\section{MATERIALS AND METHODS MATERIJALI I METODE}

\section{Study Area - Područje istraživanja}

This study was conducted in Isparta Regional Directorate of Forestry located on $36^{\circ} 49^{\prime} 24^{\prime \prime}-38^{\circ} 29^{\prime} 35$ North latitude and $29^{\circ} 19^{\prime} 45^{\prime \prime}-31^{\circ} 34^{\prime} 25^{\prime \prime}$ East longitude (Figure 1). The study area covers about 1.8 million hectares, $44 \%$ of which is covered by forests. This study contains a very wide fire observation network of 37 fire lookout towers including the neighbouring 9 towers.
The minimum, maximum and mean elevation in the region are $72 \mathrm{~m}, 2984 \mathrm{~m}$ and 1236 meters, respectively, while the mean inclination is $26 \%$. In addition to the Mediterranean climate, there are transition zones to continental Central Anatolia climate. The characteristic features of the Mediterranean climate (Lionello et al., 2006; Karatepe and Koyun, 2017) are observed in the south of the study area. Temperature increases $\left(>32^{\circ} \mathrm{C}\right)$ and precipitation decreases (mean $<20 \mathrm{~mm}$ ) in summer (Worlclim, 2019). Fire risk increases extraordinarily owing to high temperature combined with low relative humidity declining below $10 \%$ due to the impact of drying northerly winds during the period covering early June and late September (Neyiş̧̧i, 1987) considered as the fire season in the region. The annual mean precipitation is $490 \mathrm{~mm}$, while it declines to $17 \mathrm{~mm}$ on average in summer. The mean relative humidity is $60 \%$ in summer while the dominant wind direction is south (TSMS, 2019). Coniferous species account for $75 \%$ of the forests. Brutian pine (Pinus brutia Ten.) and black pine (Pinus nigra Arnold.) that are coniferous tree species very sensitive

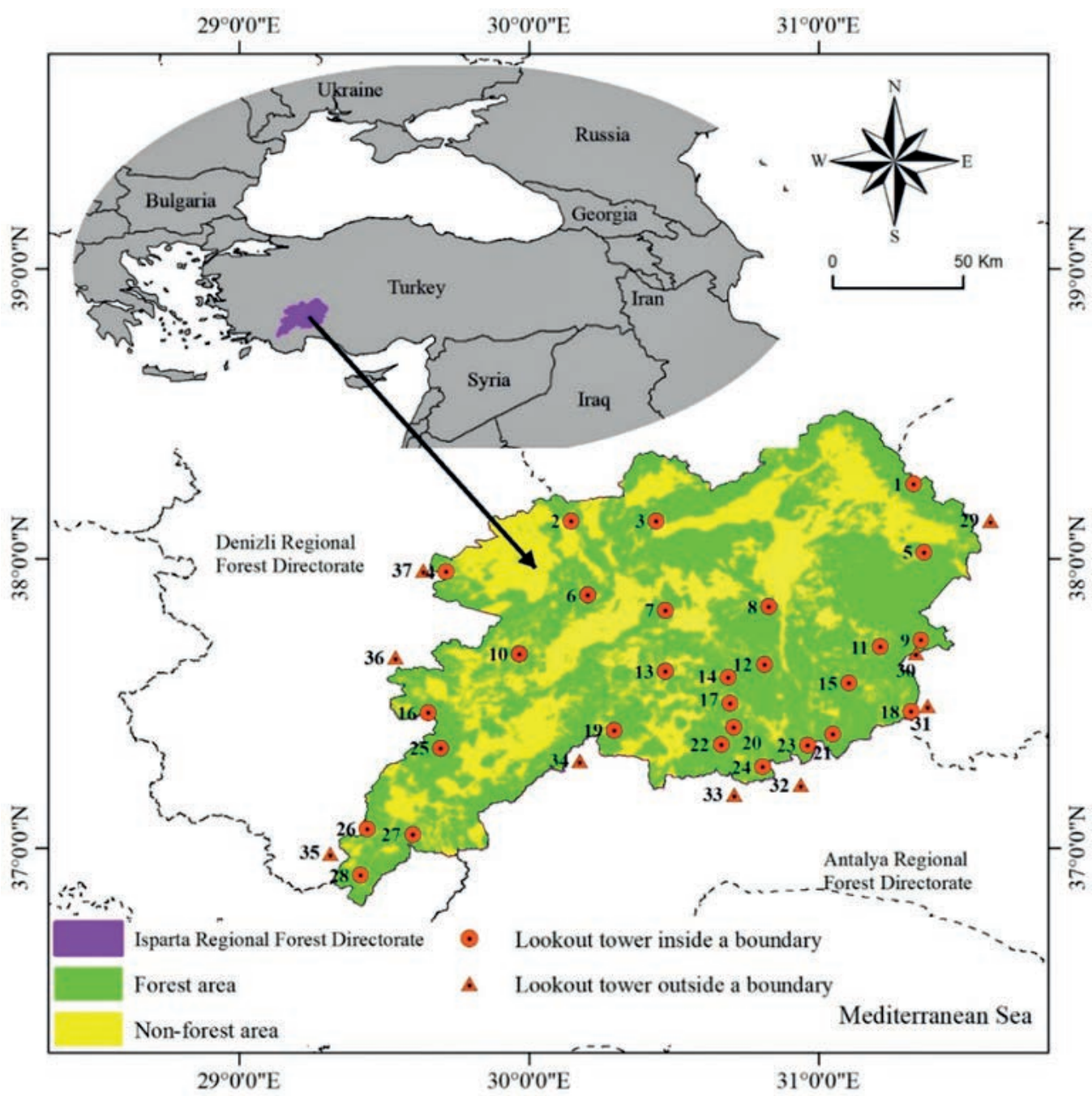

Figure 1. Location of study area

Slika 1. Lokacija istraživanog područja 


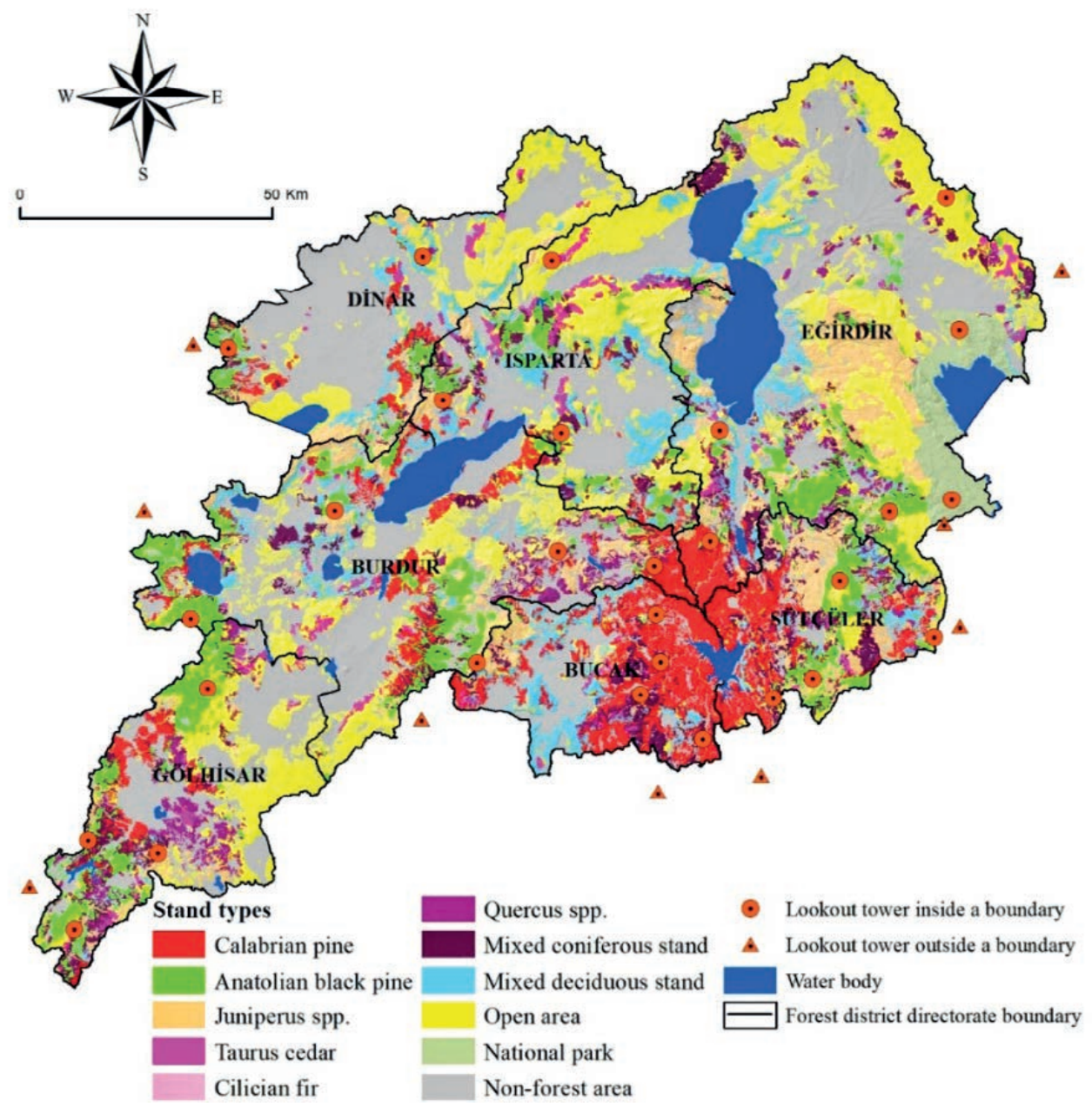

Figure 2. Spatial distribution of stand types in the study area

Slika 2. Prostorni raspored tipova sastojina u istraživanom području

to fire represent $37 \%$ of the forests. The main broad-leaved species in the region include oak (Quercus spp.) species and false acacia (Robinia pseudoacacia L.) as well as Turkish sweetgum (Liquidambar orientalis Mill.) species (Figure 2).

In the study area, tourism potential is high, settlement areas are intertwined with the forest, traffic increases on the roads passing through the forest, stubble burning practice is still sustained on the agricultural fields adjacent to the forest, which are the main human activities that further increase the fire risk. The forestry authority has 21 fire first response teams, 41 water trucks, 8 water supply tanks, 8 bulldozers, 6 graders, 104 utility motor vehicles, 41 fire pools, 46 water reservoirs, 99 water area (ponds/dams) and 500 fire workers for the organization of forest fire-fighting efforts in the region (IRDF, 2018).

\section{Geographical Dataset - Skup geografskih podataka}

The topographic variables of the study area were calculated with the help of NASA SRTM Version-3.0 $1 \operatorname{arcsec}(\sim 30$ meters) data (USGS, 2019) that could be downloaded from https://earthexplorer.usgs.gov/. Digital elevation model
(DEM) of the study area was produced by using this SRTM data. Elevation, inclination and aspect layers were driven in ArcGIS software based on DEM reported to have high horizontal and vertical accuracy (Çoban and Eker, 2009; Bildirici et al., 2017). These topographic variables were assessed together with the findings of the previous scientific studies combined with the statistics obtained from the analysis of histogram distribution between the points of origin of 719 forest fires that occurred in the region in the last decade, and the fire risk categories proposed by Bereket (2019) were determined (Table 1).

Fire risk is defined as the likelihood of a fire to start due to the nature and formation of the factors that may lead to fire (Hardy, 2005). In fact, topographic factors, human behaviours and forest characteristics were used to determine the fire risk of the forest areas for this study (You et al., 2017). All fire risk values were assigned to the relevant raster geographic data and the fire risk zones layer developed in GIS environment by Bereket (2019) was used to inquire fire risks of visible and invisible forest areas in the viewshed analysis of the towers (Jaiswal et al., 2002; Eugino et al., 2016). 
Table 1. Topographic variables used for mapping fire risk zones

Tablica 1. Topografske varijable korištene za kartiranje zona izloženih riziku od požara

\begin{tabular}{|c|c|c|c|c|}
\hline Variables & Class & Risk & Risk value & Source \\
\hline Varijable & Klasa & Rizik & Vrijednost rizika & Izvor \\
\hline \multirow{3}{*}{$\begin{array}{c}\text { Elevation (meter) } \\
\text { Nadmorska visina (metar) }\end{array}$} & $0-1100$ & $\begin{array}{l}\text { Very high } \\
\text { Vrlo visok }\end{array}$ & 5 & \multirow{4}{*}{ Bereket, 2019} \\
\hline & $1100-1800$ & $\begin{array}{l}\text { High } \\
\text { Visok }\end{array}$ & 4 & \\
\hline & $>1800$ & $\begin{array}{l}\text { Very low } \\
\text { Vrlo nizak }\end{array}$ & 1 & \\
\hline \multirow{4}{*}{$\begin{array}{l}\text { Inclination }\left({ }^{\circ}\right) \\
\text { Nagib }\left({ }^{\circ}\right)\end{array}$} & $0-5$ & $\begin{array}{l}\text { Very low } \\
\text { Vrlo nizak }\end{array}$ & 1 & \\
\hline & $5-20$ & $\begin{array}{l}\text { Very high } \\
\text { Vrlo visok }\end{array}$ & 5 & \multirow{3}{*}{$\begin{array}{l}\text { Adapted from You et al., } \\
2017 \\
\text { Prilagođeno od You et al., } \\
2017\end{array}$} \\
\hline & $20-30$ & $\begin{array}{l}\text { High } \\
\text { Visok }\end{array}$ & 4 & \\
\hline & $>30$ & $\begin{array}{l}\text { Very low } \\
\text { Vrlo nizak }\end{array}$ & 1 & \\
\hline \multirow{4}{*}{$\begin{array}{l}\text { Aspect } \\
\text { Izloženost }\end{array}$} & $\begin{array}{l}\text { Flat terrains } \\
\text { Ravni tereni }\end{array}$ & $\begin{array}{l}\text { Very low } \\
\text { Vrlo nizak }\end{array}$ & 1 & \multirow{4}{*}{$\begin{array}{l}\text { Adapted from Sağlam et al., } \\
2008 \\
\text { Prilagođeno od Sağlam et } \\
\text { al., } 2008\end{array}$} \\
\hline & $\mathrm{N}$ & $\begin{array}{l}\text { Moderate } \\
\text { Umjeren }\end{array}$ & 3 & \\
\hline & $N E, N W$ & $\begin{array}{l}\text { High } \\
\text { Visok }\end{array}$ & 4 & \\
\hline & E,SE,S,SW,W & $\begin{array}{l}\text { Very high } \\
\text { Vrlo visok }\end{array}$ & 5 & \\
\hline
\end{tabular}

Table 2. Observatory parameters for viewshed analysis

Tablica 2. Parametri osmatračnica za analizu vidljivosti

\begin{tabular}{|c|c|c|c|}
\hline Variable & Default & Used & Remarks \\
\hline Varijabla & Zadano & Korišteno & Opaske \\
\hline SPOT & & SRTM data $(30 \times 30 \mathrm{~m})$ & Elevation of the tower from the sea level \\
\hline MJESTO & & SRTM podaci $(30 \times 30 \mathrm{~m})$ & Nadmorska visina tornja \\
\hline $\begin{array}{l}\text { OFFSETA } \\
\text { OFFEST A }\end{array}$ & $1 \mathrm{~m}$ & $6 \mathrm{~m}$ & $\begin{array}{c}\text { Height of the lookout plane in the tower from the ground } \\
\text { Visina promatracke ravnine tornja s tla }\end{array}$ \\
\hline $\begin{array}{l}\text { OFFSETB } \\
\text { OFFSET B }\end{array}$ & $0 \mathrm{~m}$ & $100 \mathrm{~m}$ & $\begin{array}{l}\text { Height of smoke to be recognized at the point viewed } \\
\text { Visina dima koji se vidi u promatranom mjestu }\end{array}$ \\
\hline $\begin{array}{l}\text { AZIMUTH1 } \\
\text { AZIMUT1 }\end{array}$ & $0^{\circ}$ & $0^{\circ}$ & $\begin{array}{l}\text { Initial value of horizontal scanning angle } \\
\text { Inicijalna vrijednost horizontalnog kuta skenirranja }\end{array}$ \\
\hline $\begin{array}{l}\text { AZIMUTH2 } \\
\text { AZIMUT2 }\end{array}$ & $360^{\circ}$ & $360^{\circ}$ & $\begin{array}{l}\text { End value of horizontal scanning angle } \\
\text { Krajnja vrijednost horizontalnog kuta skeniranja }\end{array}$ \\
\hline VERT1 & $+90^{\circ}$ & $+90^{\circ}$ & $\begin{array}{l}\text { Maximum vertical angle } \\
\text { Maksimalni vertikalni kut }\end{array}$ \\
\hline VERT2 & $-90^{\circ}$ & $-90^{\circ}$ & $\begin{array}{l}\text { Minimum vertical angle } \\
\text { Minimalni vertikalni kut }\end{array}$ \\
\hline $\begin{array}{l}\text { RADIUS1 } \\
\text { RADIJUS1 }\end{array}$ & $0 \mathrm{~m}$ & $0 \mathrm{~m}$ & $\begin{array}{l}\text { Initial length of scanning } \\
\text { Inicijalna duljina skeniranja }\end{array}$ \\
\hline $\begin{array}{l}\text { RADIUS2 } \\
\text { RADIJUS2 }\end{array}$ & $\begin{array}{c}\text { Infinite } \\
\text { Beskonačno }\end{array}$ & $18 \mathrm{~km}$ & $\begin{array}{l}\text { Completion length of scanning (detection radius) } \\
\text { Završna duljina skeniranja (radijus detekcije) }\end{array}$ \\
\hline
\end{tabular}

\section{Viewshed Analysis of Fire Lookout Towers - Analiza vidljivosti promatračkih tornjeva}

Viewshed analysis is performed to determine the visible and invisible areas through $360^{\circ}$ lookouts at a certain point on the terrain from a certain elevation and at a certain radius. In addition to DEM data, the coordinates of 37 towers loca- ted in the study area were also recorded in the geographical database for viewshed analysis. Table 2 shows the observatory parameters used for the viewshed analysis made by "viewshed" function under the ArcGIS-3D analysis tools.

The elevation where the lookout is performed at the towers located within the study area, which is offsetA, was applied 
(a)

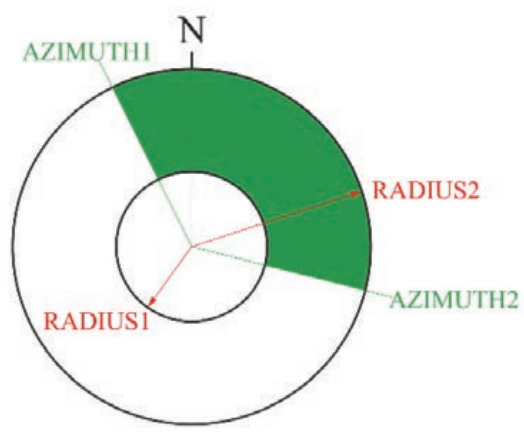

(b)

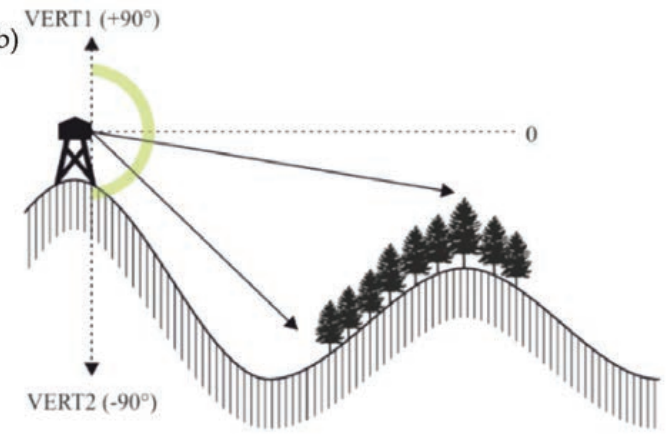

Figure 3. Observatory parameters, a) Horizontal scanning angles (Azimuth1 and Azimuth2), detection radius (Radius1 and Radius2), b) vertical scanning angles (Vert1 and Vert2)

Slika 3. Parametri osmatračnica, a) horizontalni kutovi skeniranja (Azimut1 i Azimut2), radijus opažanja (Radijus1 i Radijus2), B) vertikalni kutovi skeniranja (Vert1 i Vert2)

as 6 meters. OffsetB is the height of the smoke that an observatory at the tower is expected to recognize. Usually horizontal scanning (Azimuth) in full circle in the range of $0^{\circ}-360^{\circ}$ and maximum vertical angle range (Vert.) are used at fire lookout towers (Figure 3).

Scanning is performed with a rotation of $360^{\circ}$ at the designated scanning radius from the point where a lookout tower is located. The atmospheric condition changes the horizontal range where lookout from a tower will be effective. When there is mist and fog in the air, the range of vision decreases whereas it increases when the sky is totally clear (Catry et al., 2007). In a scientific study conducted in collaboration with the forestry authority to plan the networks of fire lookout towers in Turkey, the lookout radius of the towers was reported to be $18 \mathrm{~km}$ (Çanakçıoglu, 1993). Therefore, $18 \mathrm{~km}$ was used as scanning radius in this study. The theoretical horizontal scanning capacity of a tower is $1017 \mathrm{~km}^{2}$ which is the surface area of a circle with a radius of $18 \mathrm{~km}$. This area also contains some places that are invisible due to the topographic structure. For this reason, each of two towers has its own visibility performance. To evaluate the individual performance of the towers, the visibility index values were calculated with the following equation (1):

$$
V I=\frac{V_{A}}{S_{A}} \times 100
$$

Where VI is Visibility index, VA is Visible area from tower, SA is Scanned area. SA is the maximum scan ability and responsibility area for each tower. In the borderline, some towers can detect different management areas. The visible, invisible and areas that were outside the detection radius of each tower were identified on the data layer obtained from the viewshed analysis of the towers. After overlapping the data with the forest areas and fire risk zones, the degree of visibility of forests in the study area from the towers were determined and the fire risk of the invisible forest areas was assessed.

Viewshed analysis was also performed for the lines on the asphalt roads in the region where there was heavy traffic because the fire statistics held by the forestry authority revealed that fires had been reported over the years by ordinary people rather than fire lookout towers. The forest areas that could be scanned by people in vehicles moving on the road were determined to understand which parts of the forest areas invisible from the towers could be viewed in that way. This was done to obtain a finding to support the idea that fire lookout towers were necessary and their performance should be assessed.

In order to measure the contribution of the roads to the lookout system, the roads with heavy traffic in the study area were identified. They were the asphalt roads that connected the settlement areas. This road layer was transferred to the geographic database. Points were placed on the road line with a spacing of 100 meters using the road lines layer in the geographic database. The viewshed analysis of these points was performed. For this analysis, the variables used in the viewshed analysis of the towers (Table 2) apart from Offset $\mathrm{A}$ and the abovementioned method were used. OffsetA value was set as 1.4 meters in order to simulate the person traveling in a vehicle.

\section{RESULTS \\ REZULTATI}

Individual viewshed analysis of each tower was conducted and it was tested if they achieved visibility rate of $70 \%$ that the forestry authority expected from the towers in rugged terrain (Figure 4). Areas that were visible and invisible from each of 28 towers in the study area within the detection radius of $18 \mathrm{~km}$ were identified. The statistics obtained from the visibility analysis of the towers are given in Table 3 . The viewshed analysis results revealed that Çağlayan (2: number 2 in Figure 4), Hisartepe (4) and Çakmak (26) towers had the highest percentage of visible areas (>mean $80 \%$ ). Geledost (9), Harmancık (24) and Manastır (25) towers, however, had the lowest percentage of visible areas $(<$ mean $30 \%)$. The mean percentage of visible areas of the towers 


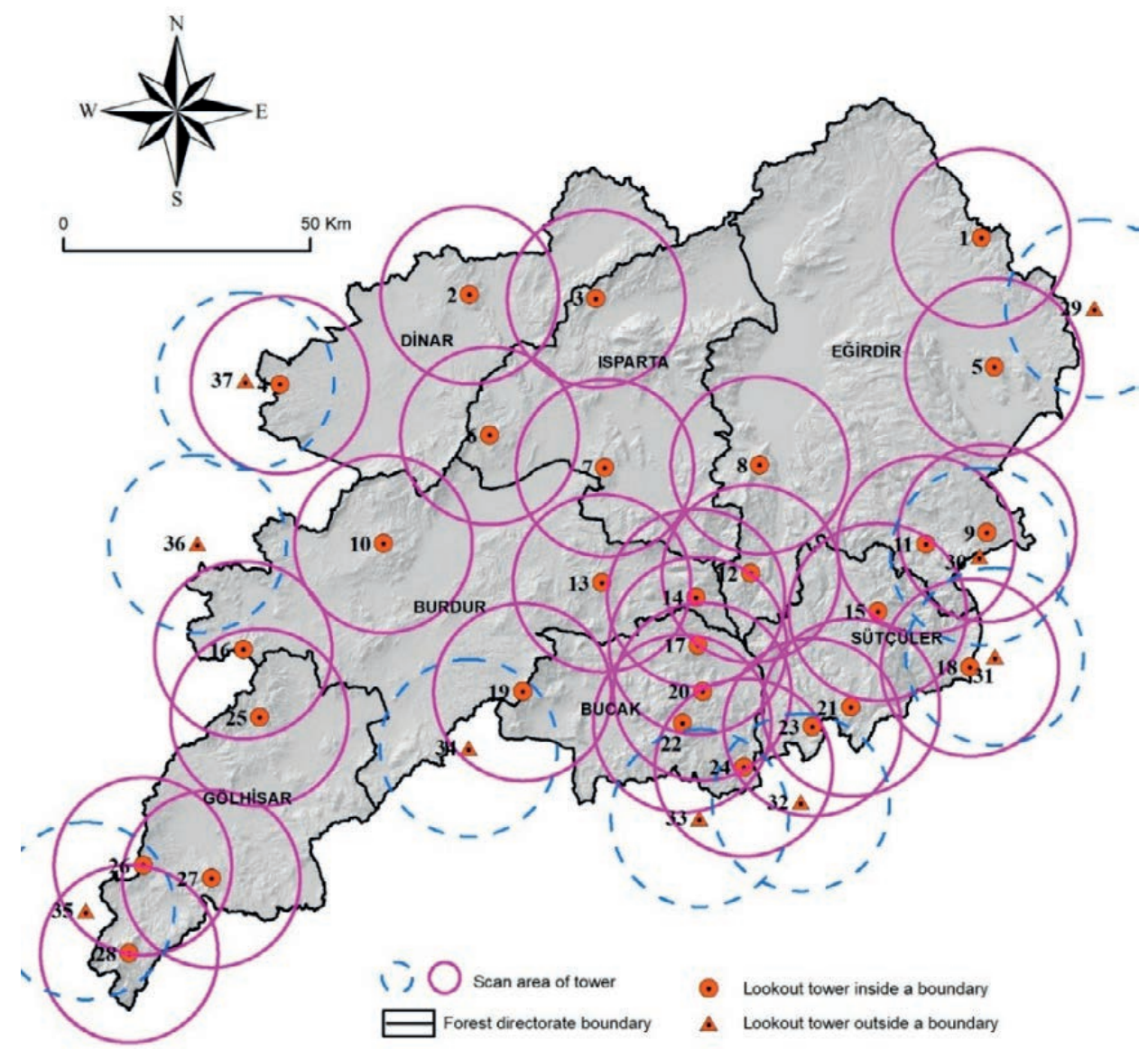

Figure 4. Detecting ranges of fire lookout towers

Slika 4. Prikaz dometa promatračkih tornjeva

Table 3. Descriptive statistics of the towers according to the visibility analysis

Tablica 3. Deskriptivna statistika tornjeva prema analizi vidljivosti

\begin{tabular}{ccccc} 
Visibility & $\begin{array}{c}\text { Visible area } \\
\text { Vidljivo } \\
\text { Vidljivost }\end{array}$ & $\begin{array}{c}\text { Invisible area } \\
\text { Područje koje } \\
\text { nije vidljivo }\end{array}$ & VI (\%) & $\begin{array}{c}\text { Tower name } \\
\text { (no) }\end{array}$ \\
$\begin{array}{c}\text { Lowest } \\
\text { Ime tornja (no) }\end{array}$ \\
$\begin{array}{c}\text { Najmanja } \\
\text { Highest }\end{array}$ & 9579.42 & 43344.99 & 18.10 & Harmancık (24) \\
$\begin{array}{c}\text { Najveća } \\
\text { Average }\end{array}$ & 68349.51 & 8353.26 & 89.11 & Çağlayan (2) \\
Prosječna & 45829.07 & 34164.67 & 58.44 & \\
\hline
\end{tabular}

VI :Visibility index (Eq.1)

Indeks vidljivosti (Eq. 1)

was $57.29 \%$. The percentage in 14 towers was higher than the average. Only 8 towers in the study area achieved the visibility standard (>\%70 visible area) designated by the forestry authority.

Forest fires are observed from the fire lookout towers in a lookout network where neighbouring towers can view one another. The contribution of the neighbouring towers that were not included in the study area besides 28 towers but could observe the forests there with their lookout capacity was also taken into consideration. With the inclusion of the neighbouring 9 towers in the viewshed analysis, their positive contribution to the fire lookout process in the study area was assessed. In this way, the areas that were visible and invisible from 37 towers in the region were identified (Table 4), thus the performance of the lookout network was

Table 4. Visibility analysis results of fire lookout towers Tablica 4. Rezultati analize vidljivosti sa promatračkih tornjeva

\begin{tabular}{|c|c|c|c|c|c|c|}
\hline \multirow{2}{*}{$\begin{array}{c}\text { Area } \\
\text { Područje }\end{array}$} & \multicolumn{2}{|c|}{$\begin{array}{l}\text { Total } \\
\text { Ukupno }\end{array}$} & \multicolumn{2}{|c|}{$\begin{array}{c}\text { Forest area } \\
\text { Šumsko područje }\end{array}$} & \multicolumn{2}{|c|}{$\begin{array}{c}\text { Non-forest area } \\
\text { Nešumsko područje }\end{array}$} \\
\hline & (ha) & $(\%)$ & (ha) & $(\%)$ & (ha) & (\%) \\
\hline $\begin{array}{l}\text { Visible } \\
\text { Vidljivo }\end{array}$ & 1018375.11 & 56.63 & 654318.35 & 59.59 & 364056.76 & 51.99 \\
\hline Invisible & & & & & & \\
\hline $\begin{array}{c}\text { Nije } \\
\text { vidljivo }\end{array}$ & 383338.85 & 21.31 & 239107.29 & 21.77 & 144231.56 & 20.60 \\
\hline $\begin{array}{c}\text { Outside } \\
\text { detection } \\
\text { radius } \\
\text { Vanjski } \\
\text { radijus } \\
\text { detekcije }\end{array}$ & 396610.90 & 39.66 & 204694.70 & 18.64 & 191916.20 & 27.41 \\
\hline $\begin{array}{c}\text { Total } \\
\text { Ukupno }\end{array}$ & 1798324.86 & & 1098120.34 & & 700204.53 & \\
\hline
\end{tabular}




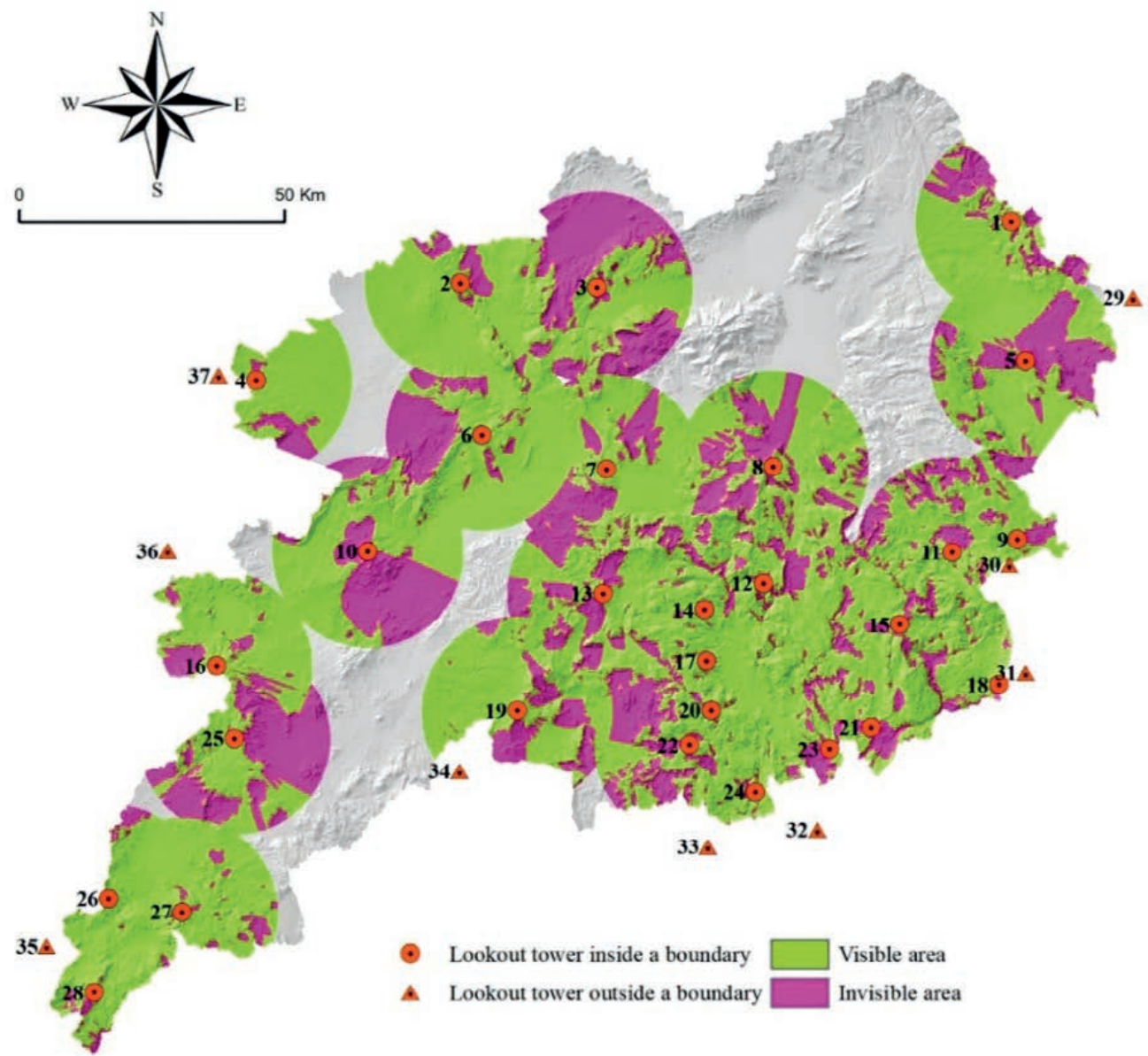

Figure 5. Visibility map of fire lookout towers

Slika 5. Karta vidljivosti sa promatračkih tornjeva

Table 5. Visible and invisible areas from one or multiple towers

Tablica 5. Vidljiva područja i područja koja nisu vidljiva s jednog ili više tornjeva

\begin{tabular}{|c|c|c|c|c|c|}
\hline $\begin{array}{c}\text { Type of area } \\
\text { Vrsta područja }\end{array}$ & (ha) & $(\%)$ & (ha) & $(\%)$ & $\begin{array}{c}\text { Total } \\
\text { Ukupno } \\
\text { (ha) }\end{array}$ \\
\hline $\begin{array}{l}\text { Visible area from } 1 \text { tower } \\
\text { Vidljivo područje } s 1 \text { tornja }\end{array}$ & 448158.80 & 40.82 & 283277.83 & 40.46 & 731436.63 \\
\hline $\begin{array}{l}\text { Visible area from } 2 \text { towers } \\
\text { Vidljivo područje } s 2 \text { tornja }\end{array}$ & 155099.61 & 14.12 & 69690.87 & 9.95 & 224790.48 \\
\hline $\begin{array}{l}\text { Visible area from } 3 \text { towers } \\
\text { Vidljivo područje } s 3 \text { tornja }\end{array}$ & 41174.16 & 3.75 & 8942.93 & 1.28 & 50117.09 \\
\hline $\begin{array}{l}\text { Visible area from } 4 \text { towers } \\
\text { Vidljivo područje } s 4 \text { tornja }\end{array}$ & 8716.50 & 0.79 & 1883.69 & 0.27 & 10600.19 \\
\hline $\begin{array}{l}\text { Visible area from } 5 \text { towers } \\
\text { Vidljivo područje } s 5 \text { tornjeva }\end{array}$ & 1112.35 & 0.10 & 261.44 & 0.04 & 1373.79 \\
\hline $\begin{array}{l}\text { Visible area from } 6 \text { towers } \\
\text { Vidljivo područje sa } 6 \text { tornjeva }\end{array}$ & 56.93 & 0.01 & 0.00 & 0.00 & 56.93 \\
\hline $\begin{array}{c}\text { Invisible area } \\
\text { Područje koje nije vidljivo }\end{array}$ & 239107.29 & 21.77 & 144231.56 & 20.60 & 383338.85 \\
\hline $\begin{array}{l}\text { Area outside the detection range } \\
\text { Područje izvan dosega opažanja }\end{array}$ & 204694.70 & 18.64 & 191916.20 & 27.40 & 396610.90 \\
\hline $\begin{array}{c}\text { Total } \\
\text { Ukupno }\end{array}$ & 1098120.34 & 100.00 & 700204.53 & 100.00 & 1798324.86 \\
\hline
\end{tabular}


determined (Figure 5). In this system that looks out for tens of square kilometres of areas, areas that were not visible due to the topographic impact although they were inside the effective detection radius, areas that were outside the detection radius as they went beyond the optimum lookout distance and areas that were visible from one tower or several towers could be identified.

The network of towers in the study area could view $56 \%$ of the overall area and $59 \%$ of the forest areas (Table 4). These results revealed that $41 \%$ of the forests in the study area were invisible. It can be suggested that the rate of invisible forestland is high for an area with fire sensitive tree species and stands (Neyişçi, 1987). Moreover, as the Mediterranean climate characteristics lead to increased danger of forest fire, the forest fire risk is maximum in summer in this region (Neyişçi, 1987). As it was possible to assess the existing tower network in three-dimensional analyses in this study, the observation capacity through the existing tower network, which was constructed without digital data and methods and fire risk analysis, and its disadvantages, could be determined.

The horizontal distance between the neighbouring towers in the network in this region ranged from $5 \mathrm{~km}$ to $55 \mathrm{~km}$. The average distance is lower between the towers inside the forests. In this way, several towers can view one place. Table 5 shows the spatial distribution of the areas that were visible from one tower or several towers according to the viewshed analysis, while their spatial distribution is shown in Figure 6. The presence of towers that are $5 \mathrm{~km}$ close to one another is an indication that the terrain where the forests in the area are distributed is very rugged. Despite that, $21 \%$ of the forests was invisible and $18 \%$ was outside the observable range of the towers.

The fire risk of the invisible forest areas in this region was assessed by overlapping the fire risk zones map developed by Bereket (2019) with the viewshed analysis map (Figure 7). The spatial distribution of areas invisible from lookout towers across the fire risk classes demonstrates that $15 \%$ of the invisible forest areas had relatively higher fire risk (Table 6). After nine towers neighbouring with the study area were included, only $1 \%$ of the previously invisible high firerisk areas became visible.

In order to test the visibility of forests in the region from the vehicles moving on the highway, viewshed analysis was conducted on points designated at an interval of $100 \mathrm{~m}$ on this road axis (Figure 8). From those roads, $52 \%$ of the forest area was visible.

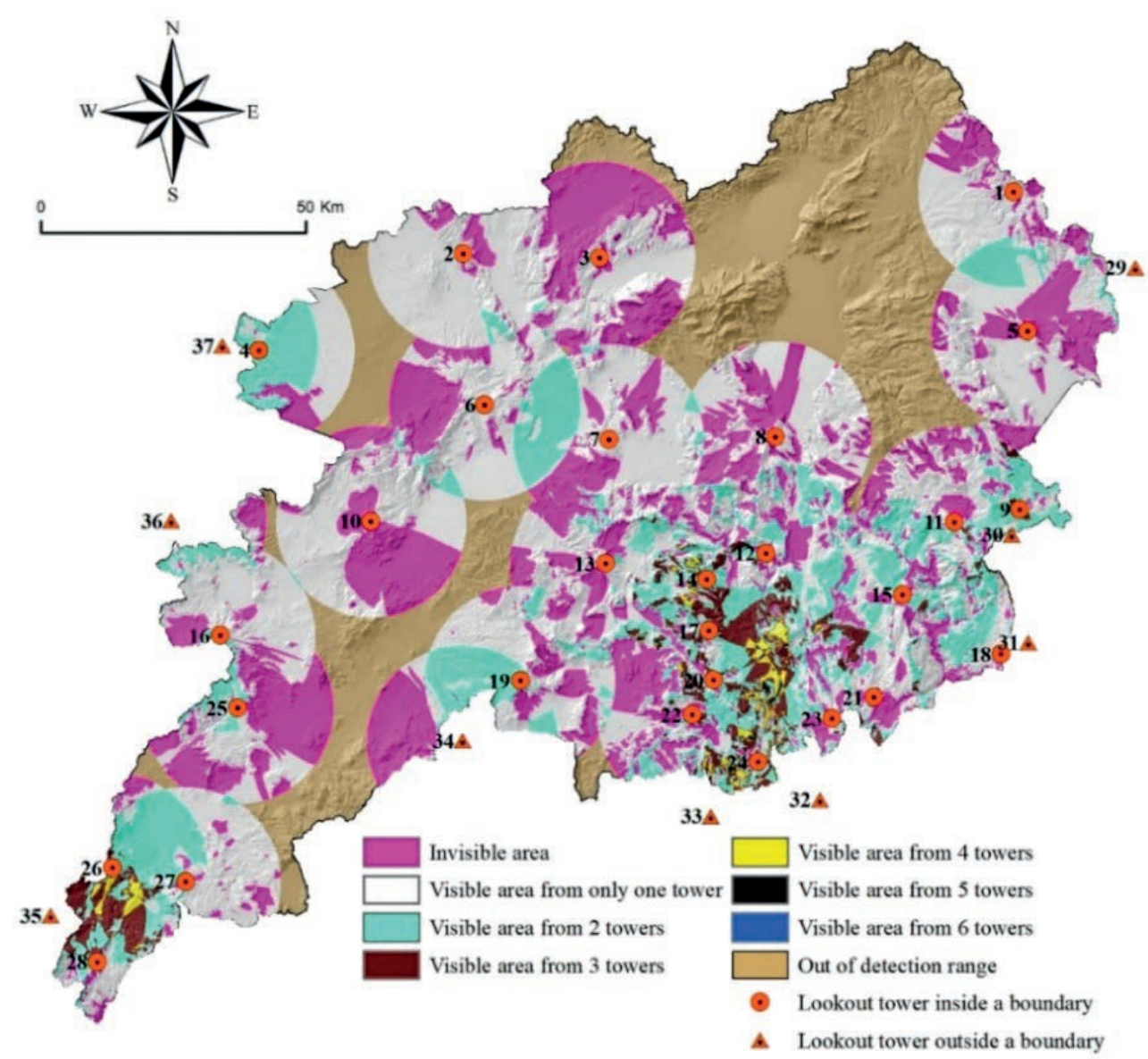

Figure 6. Spatial distribution of visibility from multiple towers

Slika 6. Prostorni raspored vidljivosti s više tornjeva 
Table 6. Distribution of visibility analysis results to fire risk classes

Tablica 6. Distribucija rezultata analize vidljivosti po klasama rizika od požara

\begin{tabular}{|c|c|c|c|c|c|c|}
\hline \multirow{2}{*}{$\begin{array}{l}\text { Field characteristics } \\
\text { Karakteristike terena } \\
\text { Fire risk class } \\
\text { Klasa rizika od požara }\end{array}$} & \multicolumn{2}{|c|}{$\begin{array}{c}\text { Visible area } \\
\text { Vidlfivo područje }\end{array}$} & \multicolumn{2}{|c|}{$\begin{array}{c}\text { Invisible area } \\
\text { Nevidljivo područje }\end{array}$} & \multicolumn{2}{|c|}{$\begin{array}{l}\text { Out of detection range } \\
\text { Izvan dosega opažanja }\end{array}$} \\
\hline & $\begin{array}{c}\text { Area (a), ha } \\
\text { Područje (a), ha }\end{array}$ & $\mathrm{a} / \mathrm{b}(\%)$ & $\begin{array}{c}\text { Area (a), ha } \\
\text { Područje (a) ha }\end{array}$ & $\mathrm{a} / \mathrm{b}(\%)$ & $\begin{array}{c}\text { Area (a), ha } \\
\text { Područje (a) ha }\end{array}$ & $\mathrm{a} / \mathrm{b}(\%)$ \\
\hline $\begin{array}{l}\text { Very high } \\
\text { Vrlo visok }\end{array}$ & 116361.54 & 10.60 & 35688.37 & 3.25 & 11084.23 & 1.01 \\
\hline $\begin{array}{l}\text { High } \\
\text { Visok }\end{array}$ & 130281.58 & 11.86 & 38297.85 & 3.49 & 13455.76 & 1.23 \\
\hline $\begin{array}{l}\text { Moderate } \\
\text { Umjeren }\end{array}$ & 226386.32 & 20.62 & 96324.86 & 8.77 & 141082.25 & 12.85 \\
\hline $\begin{array}{l}\text { Low } \\
\text { Nizak }\end{array}$ & 107411.96 & 9.78 & 39589.20 & 3.61 & 37031.84 & 3.37 \\
\hline $\begin{array}{l}\text { Very low } \\
\text { Vrlo nizak }\end{array}$ & 62621.74 & 5.70 & 26569.91 & 2.42 & 15932.94 & 1.45 \\
\hline $\begin{array}{c}\text { Total forest area } \\
\text { Ukupno šumsko područje }\end{array}$ & 643063.13 & & 236470.18 & & 218587.02 & \\
\hline $\begin{array}{c}\text { Non-forest area } \\
\text { Nešumsko područje }\end{array}$ & 361092.06 & & 135115.63 & & 203996.83 & \\
\hline $\begin{array}{l}\text { Overall forest area (b) } \\
\text { Sveukupno šumsko područje (b) }\end{array}$ & 1098120.34 & $\begin{array}{c}\text { Overall area } \\
\text { Sveukupno područje }\end{array}$ & 1798324.86 & & & \\
\hline
\end{tabular}

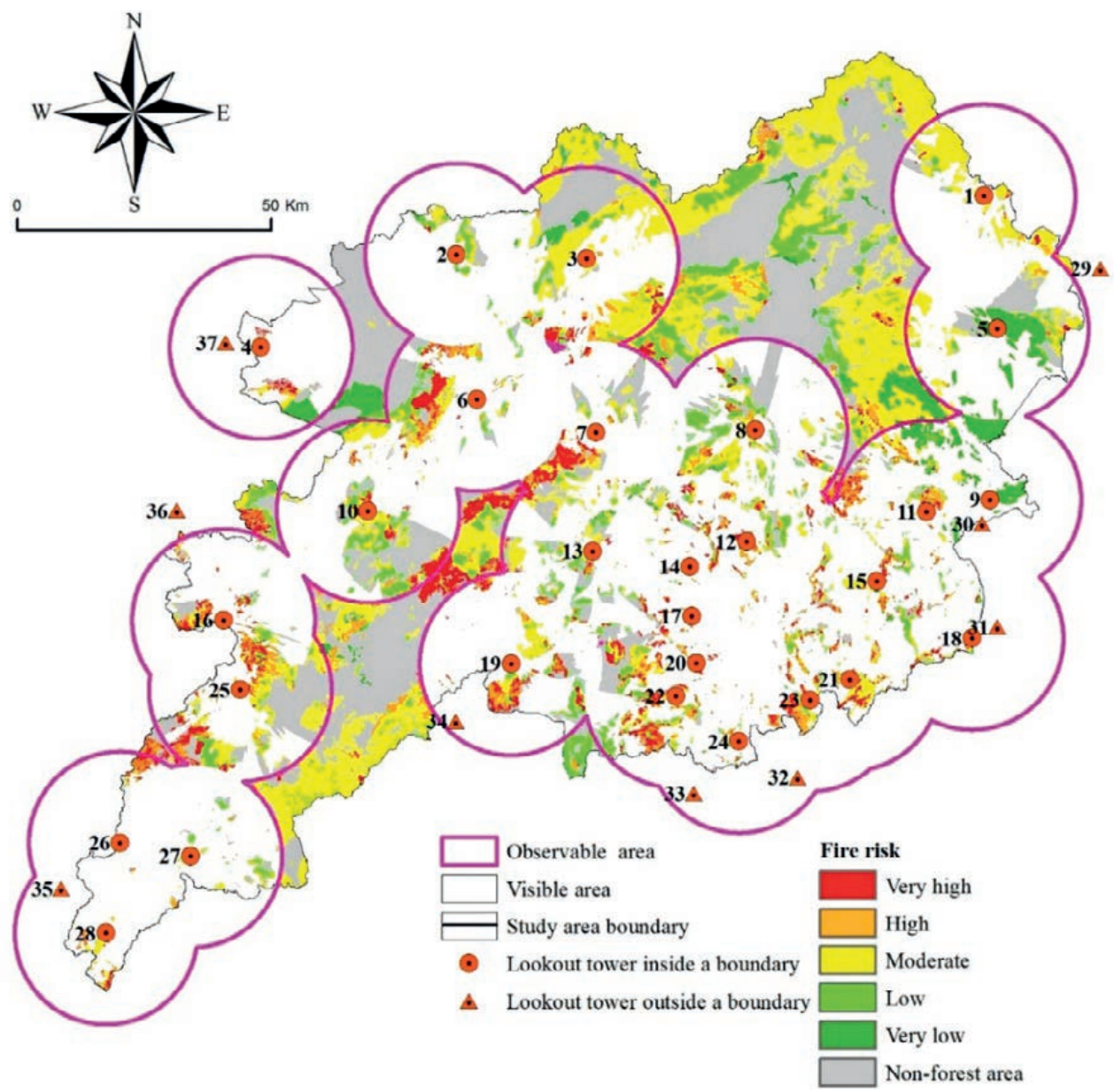

Figure 7. Spatial distribution of invisible areas to fire risk classes

Slika 7. Prostorni raspored područja koja nisu vidljiva prema klasama rizika od požara 


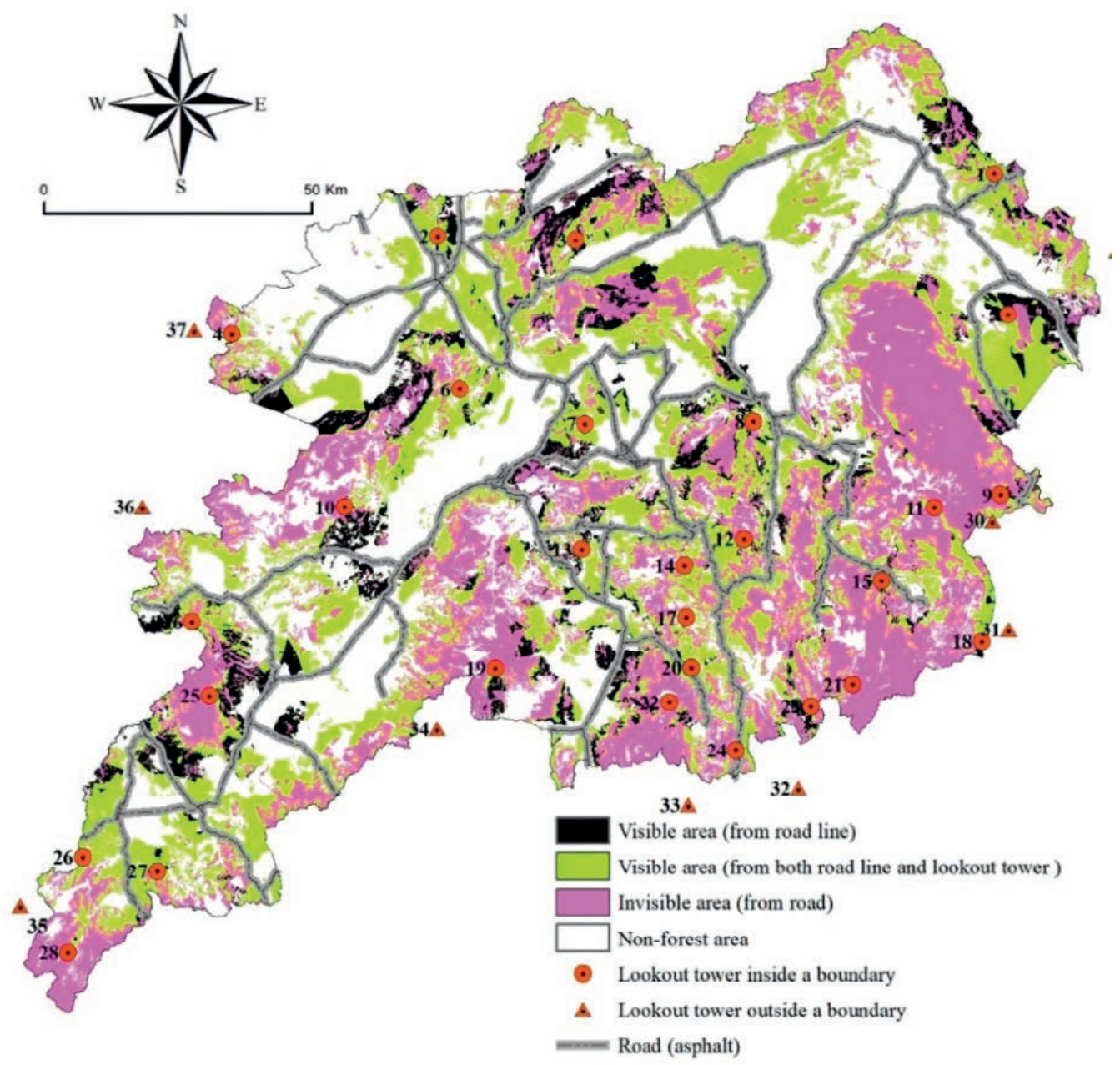

Figure 8. Visibility analysis of roads

Slika 8. Analiza vidljivosti prometnica

When the visibility map of the asphalt road line was overlapped with the visibility map of the towers, it was found that 123656 ha of forest area that had not been visible before from the towers or outside the detection range became visible. Thus, people using the roads contributed to the lookout system by $11 \%$ and ensured that $70 \%$ of the forest area in this region was visible when combined with the towers. On the other hand, 59\% of 523 thousand hectares of forest land that were not visible from the roads were visible from the towers. Therefore, fire lookout towers are still the primary lookout structure for this region.

\section{DISCUSSION RASPRAVA}

The efficiency/effectiveness/performance of the fire lookout towers is measured through the area that the towers can scan-view. Therefore, towers are supposed to be able to view an area that is scanned at 360-degree horizontal angle and minimum 120-degree vertical angle. Furthermore, the dis- tance that can be viewed with optical devices such as binoculars is also taken into account. In this study, the scanning radius of the fire lookout towers was selected as $18 \mathrm{~km}$. This value is the basic standard used by the Turkish State Forest Authority for the construction of towers (Çanakçığlu, 1993). The studies in the literature show that this scanning radius is an acceptable value. Rego and Catry (2006) calculated the effective detection radius for Portugal as $13.4 \mathrm{~km}$ for bad weather conditions and $20.6 \mathrm{~km}$ for good weather conditions. In America, effective detection range is usually 13-32 km. Especially in north America, the standard effective detection range is $24 \mathrm{~km}$ while it has been reported that $10-13 \mathrm{~km}$ detection radius could be used in areas with low range of vision in the south and southeast America (Davis, 1959; Brown and Davis, 1973). According to the United States Department of Agriculture (USDA), the observation radius of around 800 towers constructed in 1938 in the north of America was above $30 \mathrm{~km}$ on average. In Spain, the effective detection radius was reported to be $6-8 \mathrm{~km}$ for bad weather conditions and 10-20 km for optimal condi- 
tions (Ruiz, 2000). In Turkey, Küçük et al. (2017) and Göltaş et al. (2017) also conducted viewshed analysis, in which they used $10 \mathrm{~km}$ as the detection radius. As understood from these studies, the visibility of towers is lower in areas where the terrain is rolling/rugged.

The forest authority expects $70 \%$ visibility from the towers on rugged terrains. However, two-thirds of the towers in the area does not meet this expectation. This raises the following question: although the forest authority constructed these towers, why are most of them below the visibility standard it expects? To answer this question, we need to know the circumstances then. When these towers were constructed, digital data, computer technologies and GIS software were not available. For that reason, digital topographic models were not used. The findings of this study demonstrate that the location of fire lookout towers was not identified optimally. When a tower location was selected, the visible and invisible areas from a tower to be placed at that location could be automatically calculated through viewshed analysis. However, only printed maps were used at that time, it was not possible to make such calculations. Moreover, cost is one of the important elements to select the location of a tower. Maybe a more reasonable location was selected instead of constructing the towers at very steep and stiff locations without any roads.

Figure 7 shows that some of the forests that were in the scanning range of the towers but not visible were at high fire risk. This may be due to two reasons: first, as fire risk analysis and three-dimensional analyses were not performed for the construction of the towers, a mistake was made in the selection of the towers' location. Secondly, as the terrain in the area where the forests were situated was highly rugged, observation capability is limited. This is definitely an optimization problem (Korkmaz, 2004). However, it can be suggested that the location of the towers in the existing lookout network, that does not rely on an optimization solution, does not meet the expectations.

The scientific studies conducted in Turkey demonstrate that the average visibility rate of the regional fire lookout systems is below the standard. Küçük et al. (2017) reported that towers could view $47 \%$ of the overall area and $52 \%$ of the forest areas in a study they conducted in West Black Sea Region. In other studies, $52 \%, 47 \%$ and $49 \%$ of the overall area were reported to be visible from the towers in studies performed by (Aşkın, 2004; Kudu and Buğday, 2019; Göltaş et al., 2017), respectively. According to the studies conducted in Turkey, the network of towers with the highest visibility rate is in Gallipoli Peninsula with 76\% (Akbulak and Özdemir, 2008). These findings demonstrate that the fire lookout systems performed less than expected by the forestry authority. This is basically because the locations where the towers were positioned were determined according to the graphi- cal calculations on printed maps rather than utilizing the data from digital elevation model. It is now possible to position towers with economically optimal (Korkmaz, 2004) and desired visibility rate using digital data and GIS (Bao et al., 2014; Shi and Xue, 2016).

There are only a few studies conducted in Turkey in which the network of fire lookout towers was overlapped with forest fire risk zones. Küçük et al. (2017) reported that $6 \%$ of the relatively high fire risk forest areas was invisible, 15\% was outside the effective detection range. In this study, 15\% of the forest area was found to be outside the detection range and have relatively high fire risk. Taking into account these risks, we think that a more effective lookout system should be constructed in forests at high fire risk through sensitive forestry activities (Şentürk, 2018). The forest authority is aware of the fact that fire lookout towers are not sufficient in certain areas. It tries to raise awareness of local people to fight forest fires in order to compensate these gaps. Through nation-wide public awareness-raising activities, people are advised to contribute to the prevention of forest fires and notify authorities immediately in case of a fire.

The fire statistics regarding the study area from 2008 to 2018 reveal that $70 \%$ of the fire reports were submitted by citizens to the security units or fire notification line of forestry authority. Fire reports from the towers have been decreasing, especially following 2010. This is because people use mobile phones more commonly and they can directly notify the security units about the fires that occur in places close to highways where especially there is heavy traffic (Eker and Özer, 2015).

People using the inner forest roads lead to the start of forest fire on one hand due to reasons such a cigarette litter and picnic fire while on the other hand they increase the success of first response by notifying the forest authority immediately if they see a fire while travelling through these roads (Narayanaraj and Wimberly, 2012; Ricotta et al., 2018). The records show that notification in this way is much earlier than the recognition by towers (IRDF, 2018). Almost everyone has a mobile phone today, this means that every conscious individual is a fire observatory. Therefore, it can be suggested that forests that are adjacent to settlement areas and visible from the frequently-used roads are under constant observation.

Fire lookout towers not only recognize fires in the shortest time and notify the fire response teams but also provide logistic support to them during fire extinguishing activities (Belval et al., 2019). We think that the tower lookout network will continue to be used as primary system in dangerous areas, protected areas and sensitive areas. With future technological developments in digital camera systems, thermal sensors and unmanned aerial vehicles, they can be more commonly used for fire observation. We think that it 
will be more appropriate to find optimal solutions by assessing the areas at high fire risk rather than aiming at achieving $100 \%$ visibility from the towers in forests that are located on mountainous and rugged terrains such as Turkey. Furthermore, it can be suggested that a good self-check can be performed by using the methodology applied in this study when it is necessary to check the effectiveness of the existing towers and fixed lookout stations.

\section{CONCLUSIONS}

\section{ZAKLJUČCI}

The primary objective of forest fire fighting is to respond to fire before it occurs or grows to the extent that cannot be controlled. Early detection of fires can ensure success for early and moderate intervention. In this study, viewshed analysis was performed for 28 lookout towers inside the boundaries of Isparta Regional Directorate of Forestry and 9 towers outside its boundaries. The findings demonstrated that these towers could view 59\% of the forest area inside the study area. While $19 \%$ of the remaining forest area was outside the detection range of the towers, $22 \%$ was not visible due to the rugged terrain and detection limits of the towers. In this lookout system, $41 \%$ of the forest area was visible from only one tower, while $19 \%$ was visible from multiple towers. The towers built without GIS-based viewshed analysis were understood to be able to control around $40 \%$ of the forest area in this mountainous and firesensitive region. It was also found that they could not control more than 100 thousand hectares of fire-sensitive forest area. This is a weakness in fighting fire as regards early alert. Although it is not possible to reach the data that can calculate the opportunity cost of fire lookout towers from statistical point of view, it can be suggested that they decrease the damage caused by fires. Moreover, GIS-based methodology developed and used in this study can be useful to install fixed cameras or chameleon vision cameras that are capable of detecting fires because it is an important decision support system that allows for multidimensional assessment. There is a need for further studies on GIS-based methodologies that include the use of fixed camera systems and remote sensing technologies in addition to the conventional lookout towers with a view to planning the economically, technically and operationally optimal lookout system. We recommend a multidimensional structure of human and digital technology interaction to establish the optimal fire observation systems in the future.

\section{REFERENCES}

\section{LITERATURA}

- Akay, A., A. Erdoğan, 2017: Assessment of fire watch towers by using visibility analysis: The case of Dursunbey, Balıkesir, International Symposium on New Horizons in Forestry, Süleyman
Demirel University, Faculty of Forestry publication, pp. 119-125, Isparta

- Akbulak, C., M. Özdemir, 2008: The application of the visibility analysis for fire observation towers in the Gelibolu Peninsula (NW Turkey) using GIS, BALWOIS-2008, pp. 1-7, Ohrid

- Aşkin, Y., 2004: Using GIS for Kemalpaşa Mountain forest fire observation towers visibility analysis and determination of alternative observation points, $3^{\text {rd }}$ GIS Days, Fatih University publication, İstanbul. (in Turkish)

- Avci, M., M. Korkmaz, H. Alkan, 2009: An evaluation on the causes of forest fires in Turkey. $1^{\text {st }}$ Combating Forest Fires Symposium, pp. 33-41, Antalya. (in Turkish)

- Bao, A., N. Xiao, Z. Lai, H. Zhang, C. Kim, 2014: Optimizing watchtower locations for forest fire monitoring using location models, Fire Safety J 71:100-109

- Belval, E., Y. Wei, Bevers, M., 2019: Modeling Ground Firefighting Resource Activities to Manage Risk Given Uncertain Weather, Forests 10(1077):1-21

- Bereket, H., 2019: Spatial analysis of fire lookout towers: example of Isparta Forest Regional Directorate, Dissertation (Master's thesis), Süleyman Demirel University, Graduate School of Natural and Applied Sciences, Isparta. (in Turkish)

- Bildirici, İ.Ö., R. A. Abbak, 2017: Comparison of ASTER and SRTM digital elevation models at one-arc-second resolution over Turkey, Selçuk University, Journal of the Faculty of Engineering 5(1): 16-25

- Bilgili, E., B. Sağlam, E. Z. Başkent, 2001: Fire danger ratios and geographic information systems in fire management planning, Karadeniz Technical University, Journal of Science and Engineering, 4(2): 88-97

- Bilici, E., M. Eker, M. Hasdemir, A. E. Akay, 2017: Assessment of Post-fire Salvage Logging Operations in Mediterranean Region of Turkey, Šmarski list, 7-8: 363-373

- Brown, A. A., K. P. Davis, 1973: Forest fire detection. In Forest fire -Control and use, $2^{\text {nd }}$ edition. (Ed. Brown, A.A., Davis, K.P.), pp. 327-344, McGraw-Hill: NewYork

- Cao, Y., F. Yang, Q. Tang, X. Lu, , 2019: An Attention Enhanced Bidirectional LSTM for Early Forest Fire Smoke Recognition, IEEE Access 7: 154732-154742

- Catry, F.X., F.C. Rego, T. Santos, J. Almeida, P. Relvas, 2007: Forest fires prevention in Portugal - using GIS to help improving early fire detection effectiveness. Proceedings of the International Wildland Fire Conference, Seville

- Çanakçioğlu, H., 1993. Forest Protection, İstanbul University, Faculty of Forestry Publication, 3624/411, İstanbul (in Turkish)

- Çoban, H.O., C. Erdin, 2020: Forest fire risk assessment using GIS and AHP integration in Bucak forest Enterprise, Turkey. Appl Ecol Env Res 18(1): 1567-1583

- Çoban, H.O., M. Eker, 2009: Some topographic analysis with SRTM data: example of Isparta Forest Regional Directorate, Süleyman Demirel University, Faculty of Forestry Journal A(2): 76-91 (in Turkish)

- Çoban, H.O., M. Eker, 2010: Analysis of forest road network conditions before and after forest fire. 43th International Symposium on Forestry Mechanization (FORMEC-2010), 1(1): 1-11, Italy

- Daniau, A.L., F. D’errico, M.F.S. Goni, 2010: Testing the hypothesis of fire use for ecosystem management by Neanderthal and upper Palaeolithic modern human populations, Plos One 5(2): $1-10$ 
- Davis, K.P., 1959: Detection, In Forest fire. Control and use (Ed. Davis, K.P.), pp.283-303, McGraw-Hill: NewYork

- Eker, M., H.O. Çoban, 2009: Post-fire harvest and transport planning model, $1^{\text {st }}$ Combating Forest Fires Symposium, pp. 395-402, Antalya (in Turkish)

- Eker, M., D. Özer, 2015: Precision forestry in forest harvesting: Conceptual framework, Turkish Journal of Forestry 16(2):183194

- Eugenio, F.C., A.R. Dos Santos, N.C. Fiedler, G.A. Ribeiro, A.G. DA Silva, Á.B. Dos Santos, G.G. Paneto, V.R., Schettino, 2016: Applying GIS to develop a model for forest fire risk: a case study in Espírito Santo, Brazil, J Environ Manage 173: 65-71

- Garbolino, E., V. Sanseverino-Godfrin, G. Hinojos-Mendoza, 2017: Reprint of: Describing and predicting of the vegetation development of Corsica due to expected climate change and its impact on forest fire risk evolution, Safety Sci. 97: 81-87

- GDF, 2019. Forestry Statistics-2017. General Directorate of Forestry, Available online: https://www.ogm.gov.tr/ekutuphane/ Sayfalar/Istatistikler.aspx (Accessed on: 28.02.2019)

- Göltaş, M., T. Demirel, İ. Çağlayan, 2017: Visibility analysis of fire watchtowers using GIS: a case study in Dalaman State Forest Enterprise, European Journal of Forest Engineering 3(2): 66-71

- Jaiswal, R.K., S. Mukherjee, D.K. Raju, R. Saxena, 2002: Forest fire risk zone mapping from satellite imagery and GIS, Int J Appl Earth Obs 4: 1-10

- JRC, 2018: Forest Fires in Europe. European Commission, Joint Research Centre (JRC) Technical Reports, Middle East and North Africa 2017, 10. EUR 29318 EN

- Hardy, C.C., 2005: Wildland fire hazard and risk: Problems, definitions, and context, Forest Ecol Manag 211: 73-82

- IRDF, 2018: Action Plan for Combating Forest Fires of Isparta Region. Isparta Regional Directorate of Forestry, Directorate of Combating Forest Fires, Isparta (in Turkish)

- Karatepe, Y., E. Koyun, 2017: Effects of soil-bedrock properties on tree growth in Red Pine (Pinus brutia Ten.) natural regeneration sites under the influence of Mediterranean climate in Isparta Regional Directorate of Forestry, Turkish Journal of Forestry 18(1): 30-36 (in Turkish)

- Keeley, J.E., 2012: Fire in Mediterranean Climate Ecosystems - A comparative overview, Isr J Ecol Evol. 58: 123-135

- Keeley, J.E., W.J. Bond, R.A. Bradstock, J.G. Pausas, P.W. Rundel, 2012: Fire in Mediterranean Ecosystems, Cambridge University Press, pp. 3-29, New York

- Kolaric, D., K. Skala, A. Dubravic, 2008: Integrated system for forest fire early detection and management, Period Biol 11(2): 205-211

- Korkmaz, M., 2004: Determination of optimum fire observation points using cluster covering model, Süleyman Demirel University, Faculty of Forestry Journal A(1): 37-49 (in Turkish)

- Kudu, U.M., E. Buğday, 2019: Evaluation of the suitability of fire lookout tower locations (Ilgaz Forest Management Directorate Sample), Journal of Bartın Faculty of Forestry 21(2): 550-559 (in Turkish)

- Küçük, Ö., Ö. Topaloğlu, A.O. Altunel, M. Çetin, 2017: Visibility analysis of fire lookout towers in the Boyabat State Forest Enterprise in Turkey, Environ Monit Assess 189 (329): 2-18

- Küçükosmanoğlu, A., 1986: Classification of the forest fires and the causes of occurrence and spread of big forest fires in Turkey,
İstanbul University, Faculty of Forestry Journal A (36-1): 131154

- Lionello, P., P. Malanotte-Rizzoli, R. Boscolo, P. Alpert, V. Artale, L. Li, J. Luterbacher, W. May, R. Trigo, M. Tsimplis, U. Ulbrich, E. Xoplaki, 2006: The Mediterranean climate: An overview of the main characteristics and issues, Developments in Earth and Environmental Sciences 4: 1-26

- Molina-Terre'N, D.M., G. Xanthopoulos, M. Diakakis, L. Ribeiro, D. Caballero, G.M. Delogu, D.X. Viegas, C.A. Silva, A. Cardil, 2019: Analysis of forest fire fatalities in Southern Europe: Spain, Portugal, Greece and Sardinia (Italy), Int J Wildland Fire 28: 85-98

- Naama, T., B. Hanoch, R. Erez, A. Eli, K. Daniela, B. Anna, E. Eli, L. Wittenberg, 2019: Haifa fire restoration project - urban forest management: a case study, Int J Wildland Fire 28: 485-494

- Narayanaraj, G., M. Wimberly, 2012: Influences of forest roads on the spatial patterns of human- and lightning-caused wildfire ignitions, Applied Geography 32: 878-888

- Neyişçi, T., 1987: Ecology of red pine. In Red Pine Hanbook, Öktem, E. (Ed.), Forestry Research Institute Publications, 52(2): 23-56, Antalya. (in Turkish)

- Neyişçi, T., 2009: Flammable management as a means of forest fire management. $1^{\text {st }}$ Combating Forest Fires Symposium, pp.249-255, Antalya (in Turkish)

- Pausas, J.G., V.R. Vallejo 1999: The role of fire in European Mediterranean ecosystems, In Remote Sensing of large wildfires in the European Mediterranean basin, Editor Chuvieco, E., Springer-Verlag, pp. 3-16, Berlin

- Pompa-Garcia, M., R. Solis-Moreno, E. Rodriguez-Téllez, A. Pinedo-Álvarez, D. Avila-Flores, C. Hernández-Díaz, E. VelascoBautista, 2010: Viewshed analysis for improving the effectiveness of watchtowers, in the north of Mexico, The Open Forest Science Journal 3: 17-22

- Rego, F.C., F.X. Catry, 2006: Modelling the effects of distance on the probability of fire detection from lookouts, Int J Wildland Fire 15: 197-202

- Ricotta, C., S. Bajocco, D. Guglietta, M. Conedera, 2018: Assessing the Influence of Roads on Fire Ignition: Does Land Cover Matter? Fire 1(24):1-9

- Rodrigues, M., F. Alcasena, C. Vega-García, 2019: Modelling initial attack success of wildfire suppression in Catalonia, Spain, Sci Total Environ 666: 915-927

- Ruiz, E.M., 2000: Detección. In La defensa contra incendios forestales. Fundamentos y experiencias, (Ed. Munoz R.V.), pp. 17.1-17.15, McGraw-Hill/Interamaricana de España, SAU: Madrid (in Spanish).

- Sağlam, B., E. Bilgili, B.D. Durmaz, A. Kadioğullari, Ö. Küçük, 2008: Spatio-temporal analysis of forest fire risk and danger using LANDSAT imagery, Sensors 8: 3970-3987

- San-Miguel-Ayanz, J., J.M. Moreno, A. Camia, 2013: Analysis of large fires in European Mediterranean landscapes: Lessons learned and perspectives, Forest Ecol Manag 294: 11-22

- Shi, X., B. Xue, 2016: Deriving a minimum set of viewpoints for maximum coverage over any given digital elevation model data, Int J Digit Earth 9(12): 1153-1167

- Şentürk, N., 2018: Assessment of relationship between locations and distances to roadside of forest fires in Istanbul, Turkey, Appl Ecol Env Res 16(5): 6195-6204 
- TSMS, 2019: Turkish State Meteorological Service. Available online: Long term- climate statistics by provinces of Turkey, https:// mgm.gov.tr/eng/forecast-cities.aspx (Accessed on: 10.02.2019)

- USGS, 2019: Earth Resources Observation and Science (EROS) Center, United States Geological Survey, https://earthexplorer. usgs.gov/ (Access: 12.06.2019)

- Wooster, M.J., G. Roberts, A.M. Smith, J. Johnston, P. Freeborn, S. Amici, A.T. Hudak, 2013: Thermal Remote Sensing of Active Vegetation Fires and Biomass Burning Events. In: Thermal Infrared Remote Sensing. Remote Sensing and Digital Image Processing, Kuenzer, C., S. Dech, (Eds.), v.17, Springer, Dordrecht
- Worldclim, 2019: Global Climate Data. World Climate Version 2 (Free climate data for ecological modelling and GIS). http:// worldclim.org/version2 (accessed 07.06.2019)

- Wuertner, G., 2006: The Wildfire Reader: A Century of Failed Forest Policy, Island Press, pp. 89-102, Washington

- Yener, H., 2013: Determination of horizontal and vertical distribution of Calabrian pine stands in Turkey using SRTM satellite data and GIS. J Environ Biol 34: 903-915

- You, W., L. Lin, L. Wu, Z. Ji, J. Yu, J. Zhu, Y. Fan, D. He, 2017: Geographical information system-based forest fire risk assessment integrating national forest inventory data and analysis of its spatiotemporal variability, Ecol Indic 77:176-184

\section{SAŽETAK}

Brza detekcija požara i precizna identifikacija njegovog mjesta od presudne su važnosti za uspjeh u borbi protiv šumskih požara. Vatrogasni tornjevi, odnosno motrionice, te njihovo pravilno korištenje, predstavljaju prvi korak u uspješnom otkrivanju šumskih požara u Turskoj. Cilj ove studije bio je izvršiti analizu vidljivosti vatrogasnih tornjeva postavljenih u planinskom mediteranskom šumskom dijelu Turske te procijeniti njihovu učinkovitost. Za zaštitu šumskog okoliša potrebno je utvrditi funkcionalnost i kapacitet ovih tornjeva. Područja koja su s tornjeva vidljiva i nevidljiva identificirana su pomoću geografskog informacijskog sustava i digitalnih podataka o nadmorskim visinama visoke rezolucije. U analizi vidljivosti, skeniranje je izvedeno rotacijom za 360 stupnjeva u radijusu od 18 kilometara od mjesta na kojem se nalazi vatrogasni toranj. Prometnice u ovoj regiji jedan su od elemenata koji se mogu koristiti u motrenju požara. Ljudi koji putuju ovim prometnicama mogu prijaviti šumske požare pomoću mobitela. U tom smislu, učinkovitost/djelotvornost tornjeva povezana je sa šumskim cestovnim prometom. Stoga je izvršena i analiza vidljivosti prometnica radi provjere mogućnosti motrenja s cesta. Iako su na ovom području, u kojemu su crnogorične vrste drveća poput brucijskog i crnog bora vrlo osjetljive na vatru postavljena 37 promatračka tornja, $40 \%$ šuma nalaze se u području koje nije vidljivo, a 15\% tih šuma izložene su visokom riziku od požara. Preko 100 tisuća hektara područja osjetljivog na požare u ovoj regiji nije bilo moguće kotrolirati s tornjeva. Mreža tornjeva pokrivala je $56 \%$ ukupnog područja i 59 \% šumskog područja. Ljudi koji su koristili ceste doprinijeli su sustavu za detekciju požara s $11 \%$ pa je na taj način, zajedno s tornjevima, 70 \% šumskog područja u ovoj regiji bilo vidljivo. S druge strane, 59 \% od 523 tisuća hektara šumskog zemljišta koji nisu bili vidljivi $s$ cesta bili su uočljivi s tornjeva.Naglašeno je da je participativno ponašanje ljudi koji žive u šumama i koriste šumske prometnice važan dio sustava motrenja požara pri zaštiti okoliša.

KLJUČNE RIJEČI: analiza vidljivosti, opasnost od požara, osjetljivost na požar, šumski požar, šumska prometnica, Isparta 